\title{
A 100-Year Review: Regulation of nutrient partitioning to support lactation ${ }^{1}$
}

\author{
L. H. Baumgard, ${ }^{*}$ R. J. Collier, $\dagger$ and D. E. Bauman $\ddagger^{2}$ \\ *Department of Animal Science, lowa State University, Ames 50011 \\ †School of Animal and Comparative Biomedical Sciences, University of Arizona, Tucson 85721 \\ ‡Department of Animal Science, Cornell University, Ithaca, NY 14853
}

\begin{abstract}
We have seen remarkable advances in animal productivity in the last 75 years, with annual milk yield per cow increasing over 4 -fold and no evidence of nearing a plateau. Because of these gains in productive efficiency, there have been dramatic reductions in resource inputs and the carbon footprint per unit of milk produced. The primary source for the historic gains relates to animal variation in nutrient partitioning. The regulation of nutrient use for productive functions has the overall goal of maintaining the cow's well-being regardless of the physiological or environmental challenges. From a conceptual standpoint, it involves both acute homeostatic controls operating on a minute-by-minute basis and chronic homeorhetic controls operating on a long-term basis to provide orchestrated adaptations that coordinate tissues and body processes. This endocrine regulation is mediated by changes in circulating anabolic and catabolic hormones, hormone membrane receptors and intracellular signaling pathways. The coordination of tissues and physiological systems includes a plethora of hormones, but insulin and somatotropin are 2 key regulators of nutrient trafficking. Herein, we review the advances in our understanding of both conceptual and actual regulation of nutrient partitioning in support of milk synthesis and identify examples of the challenges and future opportunities in dairy science. Key words: homeorhesis, homeostasis, somatotropin, insulin, metabolic regulation
\end{abstract}

\section{INTRODUCTION}

Domesticating dairy animals played a critical role in the development of human society. Dairy products were recognized as nutritious foods as early as 4,000 BC, and today milk and dairy products are key components

\footnotetext{
Received May 28, 2017.

Accepted July 12, 2017.

${ }^{1}$ This review is part of a special issue of the Journal of Dairy Science commissioned to celebrate 100 years of publishing (1917-2017).

${ }^{2}$ Corresponding author: deb6@cornell.edu
}

of dietary recommendations by governmental agencies and public health organizations around the world. Cow's milk contains more of the essential vitamins and minerals required by humans than any other single food (Patton, 2004). Advances in lactation physiology during the last century have increased our understanding of the biological processes that allow dairy cows to use feed nutrients for the biosynthesis of milk (Appendix Table A1). Annual milk yield per cow was relatively constant over the first part of the 20th Century. However, beginning in the early 1940s, the application of scientific principles to nutrition, management, and genetics initiated a progressive improvement in milk production that continues to this day. Whereas annual milk per cow averaged about 2,000 kg from the 1920s through the early 1940s, the US dairy herd currently annually averages over 10,000 $\mathrm{kg}$ (Figure 1). Indeed, the annual herd average on some US dairy farms is $>14,000$ $\mathrm{kg}$ of milk per cow, and the current US record holder is a Wisconsin cow named Ever-Green-View My GoldET ("My Gold"), who had a 365-d milk production of $35,144 \mathrm{~kg}$ (906 kg of fat, $934 \mathrm{~kg}$ of true protein; http:// www.dairyherd.com/news/industry/new-national-milk -production-record-set). Equally impressive, the Guinness World Records recently recognized a 15-yr-old Canadian cow, Guillette E Smurf, as the lifetime record holder in milk production; Smurf's production of $216,891 \mathrm{~kg}$ in 10 lactations represents an impressive average of over $38 \mathrm{~kg}$ of milk for every day of life (http:// www.guinnessworldrecords.com/world-records/greatest -milk-yield-by-a-cow-\%E2\%80\%93-lifetime).

Historic gains in milk yield originate partly from selection and genetic improvement (50-66\%) and the remainder from advances in nutrition and management (VanRaden, 2004; Shook, 2006). Progress from applying genetic selection requires sound practices in nutrition and overall management for a cow to achieve her production potential. Likewise, production advances resulting from technology developed from basic dairy cow biology require an adequate genetic base. Examples explaining the historic gains include a better understanding of nutrient requirements, improvements in diet formulation and mixing, utilizing AI and 


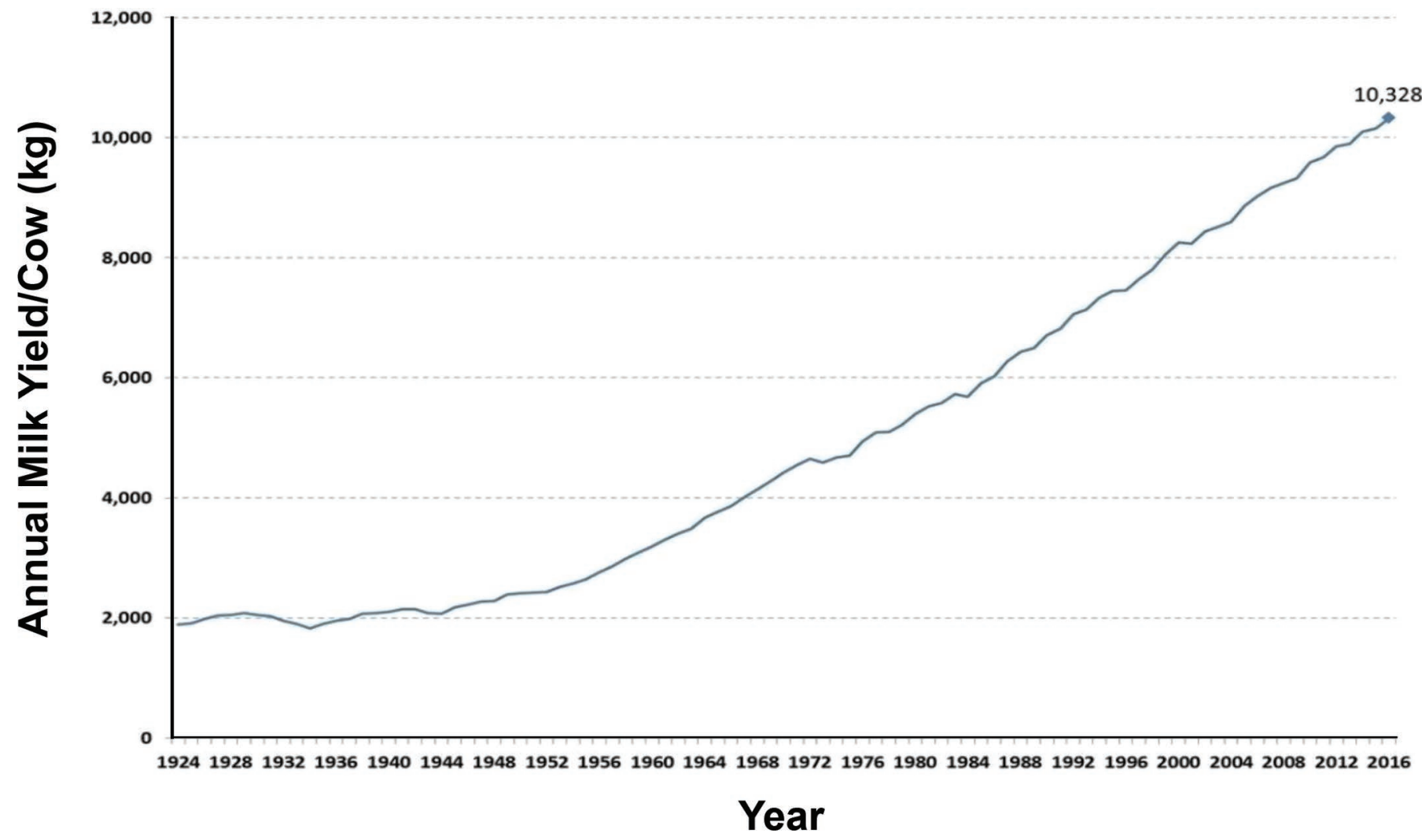

Figure 1. Average annual milk production in the United States per cow (https://quickstats.usda.nass/gov/; accessed February 20, 2017). Color version available online.

applying more accurate genetic selection methods, improved milking management practices and mastitis control, and the effective use of herd health programs to prevent disease (Collier et al., 2005). Furthermore, new technologies and management tools such as estrus synchronization, pregnancy detection, and bovine somatotropin have enhanced the production potential of dairy cows and allowed them to more nearly achieve their genetic capacity.

Lactation represents a substantial reorganization in the hierarchy of nutrient partitioning, and a dairy cow's metabolism is exquisitely coordinated to support the metabolic demands of milk synthesis. The mammary gland's synthetic capacity is so impressive that in the context of nutrient use and metabolism, Brown (1969) proposed the cow should be considered as an appendage to the udder, rather than vice versa. Herein, we will consider the cycle of life and advances in productive efficiency, review the broad concepts of regulation, and characterize specific tissue adaptations and mechanisms to support lactation (Appendix Table A1). Finally, we will speculate on upcoming challenges and opportunities for future discoveries in productive efficiency in dairy cows.

\section{PRODUCTIVE EFFICIENCY}

The continued increase in dairy cow productivity is a key component for the sustainability of the global dairy industry. Productivity or productive efficiency, defined as milk output per resource input, is improved as milk yield increases (Bauman et al., 1985; VandeHaar and St-Pierre, 2006). When the increase in milk yield/cow during the last 75 years is combined with improved crop productivity, feed use by the US dairy herd per unit of milk produced has been reduced by about $80 \%$ and carbon footprint has decreased by two-thirds (Capper and Bauman, 2013). Animal biology includes a series of processes in which dietary feed components are transformed and used to support body tissues and activities (Kleiber, 1961). Feed is consumed and digested products are assimilated and partitioned in a process governed by a physiological echelon; meeting maintenance requirements is top priority and secondary uses of absorbed nutrients are for productive functions such as milk synthesis or fetal development. Further, on a short-term basis, body reserves can be replenished or mobilized to support the hierarchical goals of nutrient trafficking. 


\section{Sources of Variation}

What are the sources of variation that have allowed for the improvements in productive efficiency over the last century? Which "cycle of life" processes have been altered by the remarkable increase in productive efficiency of dairy cows? Evaluating the processes of digestion and nutrient absorption, maintenance requirements, and the partial efficiency of nutrient use for productive functions (e.g., milk synthesis) indicates that these biological processes are only minor sources of the variation among animals, and alterations in them have contributed little to the annual gains in performance and productive efficiency (Bauman et al., 1985; Gordon et al., 1995; Agnew and Yan, 2000; Reynolds, 2004; Moraes et al., 2015). In contrast, differences in nutrient partitioning represent the primary reason for cow-tocow variation and the major source of annual improvement in milk production. High-yielding cows direct a greater portion of absorbed nutrients to the mammary gland for milk synthesis and, associated with this, they have a greater voluntary feed intake. Low-yielding cows have a lower feed intake: if they do consume more feed, they use it for excessive body fat accretion rather than milk synthesis. This nicely illustrates that increased nutrient consumption is the result of enhanced productivity (i.e., increased milk synthesis drives feed intake). Thus, selection for high milk production results in dairy cows that not only utilize more nutrients for milk synthesis but also voluntarily consume more feed to support the demands of copious milk production (Bauman et al., 1985; Reynolds, 2004). To reiterate, during the last century, we have improved our understanding and definition of nutrient requirements, but only minimal changes have occurred in the extent of digestibility, the actual requirements for maintenance, or the efficiency of synthesizing a unit of milk.

High-producing cows have a greater productive efficiency because a larger portion of total nutrient intake is used to synthesize milk. Nutrient use for maintenance represents a fixed cost, and the effect of this on productive efficiency is illustrated by calculations based on historical milk yield. In 1944, about $69 \%$ of the average cow's ME requirement was used for maintenance and approximately $31 \%$ used for milk synthesis. This contrasts to 2016 where the proportion used for maintenance has declined to about 35\% of the ME requirement and the amount used for milk synthesis has more than doubled $(\sim 65 \%)$. Even more impressive, during her record lactation, "My Gold" (the current world-record holder) utilized about $16 \%$ of her ME requirement for maintenance and over $84 \%$ for milk synthesis. Thus, as milk yield per cow increases, the fixed cost of meeting the cow's maintenance require- ment is proportionally reduced (Bauman et al., 1985; VandeHaar and St-Pierre, 2006; Gerber et al., 2011). This is a phenomenon generally referred to as "dilution of maintenance" and is usually considered in terms of feed resources per unit of milk, but the sustainability advantages of diluting maintenance also apply more broadly to all input costs of producing milk, including renewable and nonrenewable resources as well as the costs for facilities and labor. Consequently, diluting maintenance costs is a key component to the annual improvements in milk production, sustainability of the dairy industry, and farm profitability.

\section{Productivity and Stress}

With each advance in dairy production over the last century, some have expressed concern that cows are being "pushed too far," thereby causing metabolic stress and compromising cow health and well-being. Over 50 years ago, Sir John Hammond evaluated this claim in his review of lactational physiology and found no support for the concern. Hammond concluded, "the physiological limits to intensive milk production are... only limited by our knowledge concerning the specific nutrients required for milk production" (Hammond, 1952). Subsequent re-evaluations of the biological limits of milk production by Bauman et al. (1985), Knight et al. (2004), and Reynolds (2004) reached conclusions similar to those of Hammond and, indeed, productivity has increased at a consistent annual rate of about $140 \mathrm{~kg} /$ cow during the last half-century. Ostensibly, a plateau exists where the biological controls and management practices supporting lactation are maximized, but there is no evidence that we are nearing it (Figure 1). The current world record of $>35,000 \mathrm{~kg}$ of annual production indicates the potential upper limit and suggests that future herd averages may be $>3$-fold higher than today's average.

Two main arguments are often proposed for reducing the rate or even stopping gains in farm animal efficiency: (1) that high production and increased productive efficiency are contradictory to the concept of "sustainable" agriculture; and (2) that increasing milk yield is contrary to cow welfare and well-being. For some, the concepts of food production efficiency and environmental sustainability are perceived to be mutually exclusive, as discussed by Roche and Edmeades (2004). Similarly, in a review of dairy cow welfare, some have argued that it is necessary to stop using genetic selection and conventional nutritional management and nutrition practices to increase milk yield because these approaches have resulted in stressed cows, in which normal biological controls are overtaxed (Broom, 1999; Oltenacu and Broom, 2010). When these arguments 
are examined more closely, it is apparent that in fact the opposite is true. First, life-cycle analysis of dairy farms has demonstrated that increasing productivity is a major component of improving both sustainability and profitability (Gerber et al., 2011; Capper and Bauman, 2013; FAO, 2013). Second, advancements in the application of genetic selection techniques and management improvements are successful and sustainable because they have altered the biological controls in a coordinated manner (Hammond, 1952; Bauman et al., 1985; Knight et al., 2004; Reynolds, 2004). For any system to be truly sustainable it must, by definition, be efficient, and today, dairy herds with high production also have excellent fertility, low somatic cell counts, and minimal metabolic problems (Santos et al., 2010; Bauman and Capper, 2011; Ferguson and Skidmore, 2013). Rather than the biological controls of high-producing cows being at discord with increased performance, it is the improvements in biological control systems and management practices and the presence of minimal stress that allow for the increases in milk yield and gains in productive efficiency. In fact, it is only when the coordination of nutrient use is inadequate or an imbalance occurs that animal well-being and performance are compromised. The claim that "high production is stressful" is an oxymoron; optimal and efficient milk production can be achieved only when stress is minimal or absent, whereas the presence of stress prevents maximal production because it increases maintenance costs and compromises well-being.

\section{CONCEPTS OF REGULATION}

The primary goal in the regulation of physiological processes is to maintain an animal's well-being regardless of the physiological situation or environmental challenges. Lactation is a physiological state in which regulation is of special importance because the mother must partition nutrients to support synthesis of milk, thereby ensuring the survival of her nursing neonate, and to maintain her own health and well-being. Thus, the control of nutrient partitioning and coordination of metabolism during lactation allows for the production of copious milk while also preserving dam well-being. A cow's well-being is dependent on acute regulation of nutrient use and biological processes every second. During lactation, there must also be a chronic level of regulation to ensure the mammary glands are provided an adequate supply of nutrients for milk synthesis. From a conceptual basis, homeostasis and homeorhesis represent the 2 types of regulation.

The concept of homeostasis was first crystallized by Cannon (1929) as the condition of relative uniformity that results from organismal adjustments to environ- mental changes. He emphasized that dynamic regulation and coordination were key features of homeostasis. From an operational standpoint, homeostatic controls operate on an acute moment-to-moment basis so that, despite challenges from the external environment, different tissues and organs are "all working cooperatively" to maintain physiological equilibrium. Numerous examples of the multiple compensatory mechanisms functioning to maintain physiological symmetry have been described in organisms, especially mammals. Homeostatic mechanisms include the regulation of vital functions such as maintenance of body temperature, blood $\mathrm{pH}$, and body defense mechanisms. Many homeostatic mechanisms involve metabolic coordination, and examples include maintaining steady-state concentrations of key circulating nutrients, 2 of which (glucose and calcium) are especially important in lactating cows. In fact, glucose was one example used by Cannon (1929) to illustrate the concept of homeostasis. Glucose supply is of critical importance for many tissues and physiological processes, and the performance and health of the dairy cow is dependent on the maintenance of glucose homeostasis (Bell, 1995; Beever et al., 1999). Over the short term, homeostatic controls, primarily insulin and glucagon, maintain a relatively constant supply of glucose to peripheral tissues by promoting glucose storage following a meal and subsequent mobilization and catabolism from hepatic and muscle glycogen stores, respectively, during the postabsorptive period (Bauman and Elliot, 1983; Vernon and Sasaki, 1991). Thus, acute regulation of plasma glucose concentration by the reciprocal actions of insulin and glucagon ensures the proper balance in glucose supply and utilization by extra-mammary tissues in support of lactation.

The second broad type of biological regulation is homeorhesis, which was defined as the "orchestrated changes for priorities of a physiological state" (Bauman and Currie, 1980; Bauman, 2000). The concept originated from considering how physiological processes are regulated during pregnancy and lactation (Bauman and Currie, 1980), and was subsequently extended to growth (Bauman et al., 1982). Although not defined as such, Hammond (1947) clearly had this concept in mind when he emphasized how circulating nutrient utilization differs by tissue depending upon the physiological states. These physiological states represent biological situations where the orchestration involves most organs and physiological processes in the body and includes the metabolism of all macro- and micronutrient classes. Subsequently, the concept of homeorhesis has been extended to other life-cycle states and physiological situations, including pathological conditions where chronic adaptations in biological processes are required to achieve the physiological stability necessary 


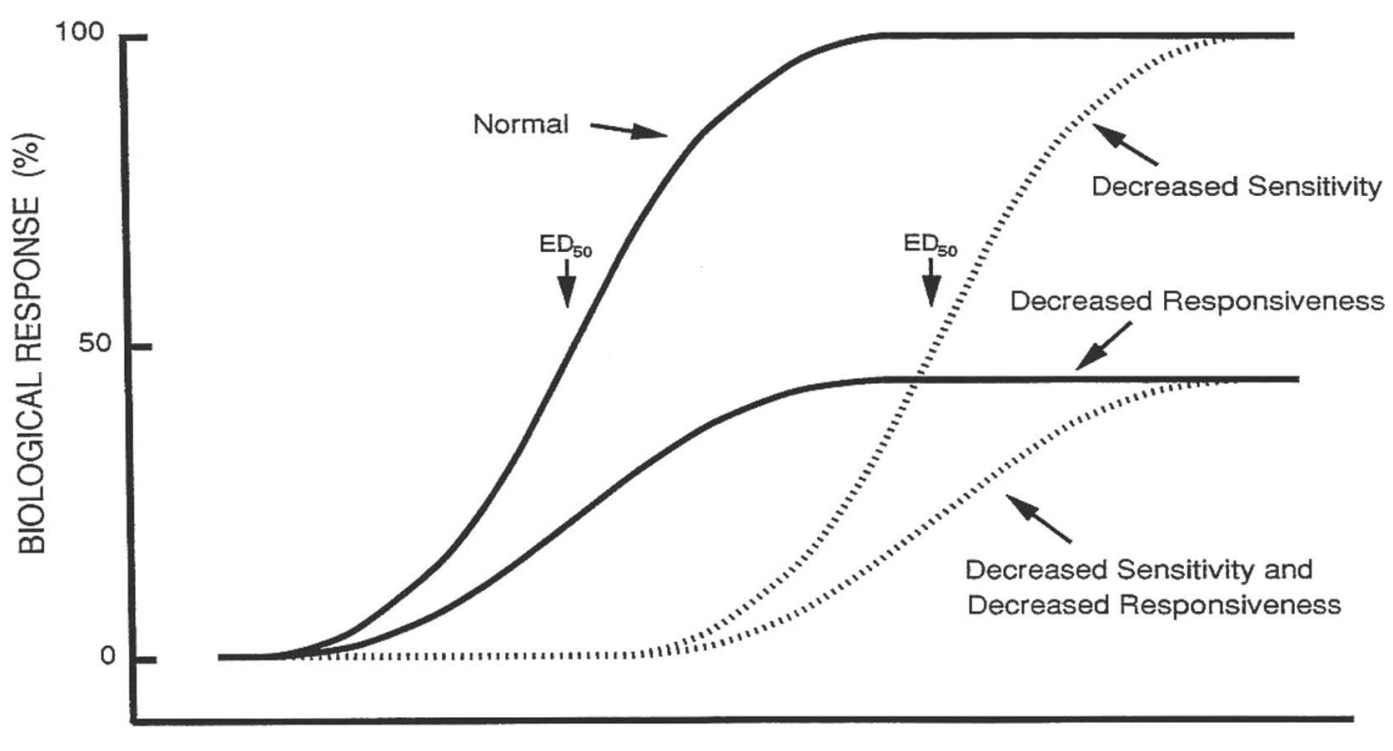

LOG HORMONE CONCENTRATION

Figure 2. Schematic representation of changes in tissue response to hormonal signals, specifically changes in responsiveness (maximal response, $\mathrm{R}_{\max }$ ) or sensitivity (hormone concentration at half-maximal response, $\mathrm{ED}_{50}$ ). Representation depicts a decrease in sensitivity, decrease in responsiveness, or decrease in both. Figure created by the authors based on a similar figure in Kahn (1978).

for survival (Bauman, 2000; Collier et al., 2005). Thus, homeorhetic regulation involves coordination of physiological processes in support of a dominant physiological state or chronic situation. Key features of homeorhesis are (1) that it is chronic in nature, involving regulation occurring over hours and days versus seconds and minutes required for most examples of homeostatic regulation; (2) its simultaneous influence on multiple tissues and systems results in an overall coordinated response; and (3) mediation involves altered tissue responses to homeostatic signals. This latter aspect represents the key to understanding the mechanistic interrelationship between homeostasis and homeorhesis (Bauman and Elliot, 1983; Vernon, 1989; Bell and Bauman, 1997).

A schematic representation of the ability of homeorhetic controls to alter tissue response to homeostatic signals is depicted in Figure 2. The interaction can involve increases or decreases in tissue responsiveness, tissue sensitivity, or both. The terms "responsiveness" and "sensitivity" were defined by Kahn (1978) to distinguish different aspects of insulin resistance in human type II diabetes. Using terminology analogous to $V_{\max }$ and $K_{m}$ as applied in enzyme kinetics, whole-body dose-response relationships between insulin and insulin action involved calculation of maximal response $\left(\mathrm{R}_{\max }\right)$ and insulin concentration at half-maximal response $\left(\mathrm{ED}_{50}\right)$. Thus, $\mathrm{R}_{\max }$ represented insulin responsiveness, which Kahn (1978) characterized as an index of postreceptor metabolic capacity, and $\mathrm{ED}_{50}$ reflected insulin sensitivity, considered to represent an index of receptor function-number, binding affinity, or signal transduction. Thus, changes in responsiveness and sensitivity provide insight as to potential mechanisms that explain altered tissue responses to support lactation (Bell and Bauman, 1997).

\section{ACTUALIZED REGULATION}

A dairy cow's ability to regulate nutrient use is most critical at the onset of lactation. Coordination of metabolic processes is the central characteristic of the physiological adaptations that occur to support lactation and they include many, perhaps most, body tissues and involve all nutrient classes - carbohydrate, protein, fat, minerals, and vitamins. The overall net effect is that the increase in mammary metabolic rate and milk synthesis coincides with altered extra-mammary metabolism so that an adequate quantity and pattern of nutrients to support milk synthesis is ensured. A partial list of the metabolic adaptations occurring during the successful transition to lactation is presented in Table 1. Even this partial listing demonstrates the wide range of metabolic processes that are altered in an orchestrated manner. Several excellent reviews have summarized quantitative details and specific references relating to the physiological adaptations that occur to support lactation (Bauman and Elliot, 1983; Vernon, 1989; Bell, 1995; Chilliard, 1999; Drackley, 1999; McNamara, 2015). 
Glucose is a particularly important metabolite during lactation, and biological adaptations prioritized to ensure its availability to the mammary gland serve as an example. At the onset of lactation, there is a marked increase in mammary glucose utilization, primarily for lactose synthesis. Total glucose turnover in a high-producing cow can exceed $3 \mathrm{~kg} / \mathrm{d}$, with up to $85 \%$ being used by the mammary glands. Lactose is the primary osmotic regulator of milk volume, and the synthesis of lactose alone utilizes 65 to $70 \%$ of the cow's total glucose turnover. If there is an imbalance between the availability and requirement for glucose, ketosis may result and well-being is compromised. To ensure an adequate glucose supply to support lactation, biological regulation involves a series of orchestrated changes that include increased hepatic rates of gluconeogenesis, decreased glucose uptake and use by adipose tissue and muscle, and a shift in whole-body nutrient oxidation so less glucose is used as an energy source (Table 1).

The role of specific homeorhetic controls in regulating these biological adaptations has been reviewed elsewhere (Vernon, 1989; Vernon and Sasaki, 1991; Bell and Bauman, 1997; Chilliard, 1999). However, an important component of the mechanism involves altered tissue set points and responses to homeostatic controls as described earlier; several examples that occur with the onset of lactation are provided in Table 2. Those related to insulin are of special importance, and hypoinsulinemia coupled with altered tissue responses to insulin is one of the best-characterized examples. At the onset of lactation, glucose-stimulated pancreatic insulin secretion is blunted (Rhoads et al., 2004). Insulin's ability to stimulate glucose disposal by muscle is also reduced and whole-body and tissue-specific dose-response relationships indicate this involves both reduced sensitivity and responsiveness (Figure 3). Insulin's ability to stimulate adipose glucose uptake is also reduced and insulin is less effective at inhibiting hepatic gluconeogenesis (Table 2). The net effect is that these glucose-related metabolic alterations are coordinated with the increase in glucose use by the mammary gland. Thus, homeostatic controls still function acutely to maintain steady-state concentrations of circulating glucose during lactation, but on a chronic

Table 1. Partial list of physiological adaptations that occur to support lactation in dairy cows ${ }^{1}$

\begin{tabular}{|c|c|}
\hline Process or tissue & Response \\
\hline Mammary tissue & $\begin{array}{l}\text { Increased number of secretory cells } \\
\text { Increased nutrient use } \\
\text { Increased blood supply }\end{array}$ \\
\hline Feed intake & Increased quantity \\
\hline Digestive tract & $\begin{array}{l}\text { Increased size } \\
\text { Increased absorptive capacity } \\
\text { Increased rates of nutrient absorption }\end{array}$ \\
\hline Liver & $\begin{array}{l}\text { Increased size } \\
\text { Increased rates of gluconeogenesis } \\
\text { Increased glycogen mobilization } \\
\text { Increased protein synthesis }\end{array}$ \\
\hline Adipose tissue & $\begin{array}{l}\text { Decreased de novo fat synthesis } \\
\text { Decreased preformed fatty acid uptake } \\
\text { Decreased fatty acid re-esterification } \\
\text { Increased lipolysis }\end{array}$ \\
\hline Skeletal muscle & $\begin{array}{l}\text { Decreased glucose utilization } \\
\text { Decreased protein synthesis } \\
\text { Increased protein degradation }\end{array}$ \\
\hline Bone & Increased $\mathrm{Ca}$ and $\mathrm{P}$ mobilization \\
\hline Heart & Increased cardiac output \\
\hline Plasma hormones & $\begin{array}{l}\text { Decreased insulin } \\
\text { Increased somatotropin } \\
\text { Increased prolactin } \\
\text { Increased glucocorticoids } \\
\text { Decreased triiodothyronine (T3) and thyroxine (T4) } \\
\text { Decreased IGF-1 }\end{array}$ \\
\hline
\end{tabular}


Table 2. A partial list of alterations in the response to homeostatic responses that occur in different tissues and processes during lactogenesis and early lactation in ruminants ${ }^{1}$

\begin{tabular}{lll}
\hline Process or tissue & Homeostatic control & Response to altered set-points \\
\hline Feed intake & Multiple controls & $\uparrow$ Appetite and satiety set-point \\
Adipose tissue & Insulin & $\downarrow$ Lipogenesis \\
& Catecholamines & $\downarrow$ Uptake of preformed fatty acids \\
& Adenosine & $\uparrow$ Stimulation of lipolysis \\
Skeletal muscle & Insulin & $\downarrow$ Inhibition of lipolysis \\
& & $\downarrow$ Plucose uptake \\
& & $\downarrow$ Amino acid uptake \\
& Insulin & $\uparrow$ Protein degradation \\
Liver & Insulinotropic agents & $\downarrow$ Gluconeogenesis \\
Pancreas & Insulin & $\downarrow$ Insulin release \\
Whole animal & & $\downarrow$ Glucose oxidation \\
& &
\end{tabular}

${ }^{1}$ Adapted from Bauman and Elliot (1983) and Bauman (2000).

basis, homeorhetic controls have orchestrated a series of adaptations in both biological processes and extramammary metabolism to ensure the mammary gland is provided with an adequate quantity of glucose and a pattern of other nutrients to support milk synthesis (Bauman, 2000).

The management of body energy reserves provides a second example where the coordinated regulation of physiological processes is essential for a successful transition at the onset of lactation (McNamara, 1991, 2015). All mammals draw on body energy reserves to support metabolic demands during early lactation and this results in an increase in circulating nonesterified fatty acids (NEFA) and ketones. The use of energy reserves at the onset of lactation varies among mammalian species, with dairy cows being intermediate in the extent and duration compared with other mammals (Bauman, 2000). In high-producing dairy cows, the uti-

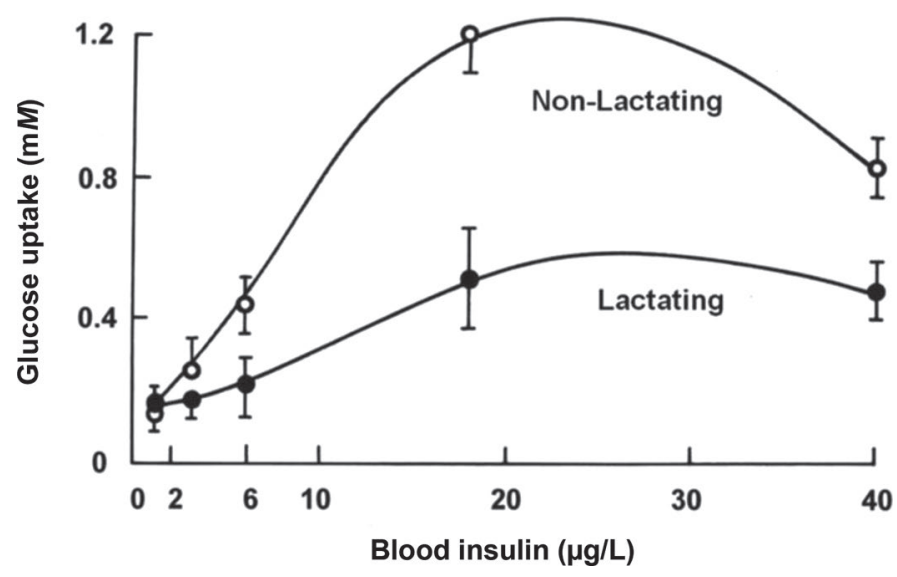

Figure 3. Effects of physiological state on insulin action in skeletal muscle. Adapted from Vernon (1986) with permission of the Hannah Research Institute (Ayr, UK). lization of body energy reserves and the mobilization of body fat in the first month postpartum can be energetically equal to over one-third of the milk produced (Bauman and Currie, 1980). This period of negative energy balance (NEBAL; Figure 4) is associated with a variety of metabolic changes that are implemented to support the dominant physiological condition of lactation (Bauman and Currie, 1980; Bell, 1995; Drackley, 1999). Mechanisms include an attenuation in adipose tissue response to homeostatic signals (Table 2). In addition to the aforementioned reduction in insulin's ability to stimulate glucose uptake by adipose tissue, there is a reduction in insulin's ability to inhibit lipolysis. Furthermore, the lipolytic response of adipose tissue to catecholamines and adenosine, 2 key homeostatic regulators of lipid mobilization, is enhanced in early lactation (Table 2). This is illustrated by the lipolytic response to an epinephrine challenge shown in Figure 5 , and by several studies demonstrating adaptations in $\beta$-adrenergic receptors, tissue responsiveness, hormonesensitive lipase (HSL) activity, perilipin, caveolin, $\beta-2$ adrenergic receptor, and HSL message (McNamara, 2015). Detailed dose-response studies with cattle and sheep indicate the cellular mechanism may be postreceptor, based on the observed increase in $R_{\max }$ with little or no effect on $\mathrm{ED}_{50}$ (Guesnet et al., 1987; McNamara, 1988; Vernon et al., 1991).

Several hormones have been proposed to function as homeorhetic controls, including somatotropin (ST), prolactin, and corticoids (Vernon and Sasaki, 1991; Bell, 1995; Chilliard, 1999). In particular, the role of ST as a homeorhetic control is well established, and it plays a key role in many of the metabolic adaptations that occur with the onset of lactation (Bell and Bauman, 1997). Furthermore, the production of recombinant bST (rbST) has provided research opportunities to more completely characterize its mechanism as a 
homeorhetic governor. Administering rbST to lactating cows increases milk production, and the mechanism includes a series of biological adaptations similar to those detailed in Tables 1 and 2 (Bauman and Vernon, 1993; Etherton and Bauman, 1998). Thus, consistent with the concept of homeorhesis, rbST both increases milk synthesis by the mammary glands and orchestrates other body processes in a manner to provide the necessary nutrients to support the increase in milk yield.

Circulating ST concentrations also increase at the onset of lactation (Figure 4) and are greater in genetically superior cows (Hart et al., 1978). During NEBAL, somatotropin promotes NEFA export from adipose tissue by increasing the lipolytic response to $\beta$-adrenergic signals (Figure $6 \mathrm{~A}$ ) and by reducing the lipogenic and antilipolytic responses to insulin (Figure 6B; Bauman and Vernon, 1993). This reduction in systemic insulin sensitivity is coupled with a decrease in circulating blood insulin levels (Figure 4). The reduction in insulin action allows for adipose lipolysis and NEFA mobilization (Bauman and Currie, 1980). Not surprisingly, reduced circulating insulin is also a key mediating factor by which high-producing cows partition nutrients away from storage and toward mammary utilization (Figure 4). Increased circulating NEFA are typical in "transitioning" and undernourished cows and represent (along with NEFA-derived ketones) a significant source of energy (and precursors for milk fat synthesis) for cows in NEBAL. The severity of calculated NEBAL is positively associated with circulating NEFA levels

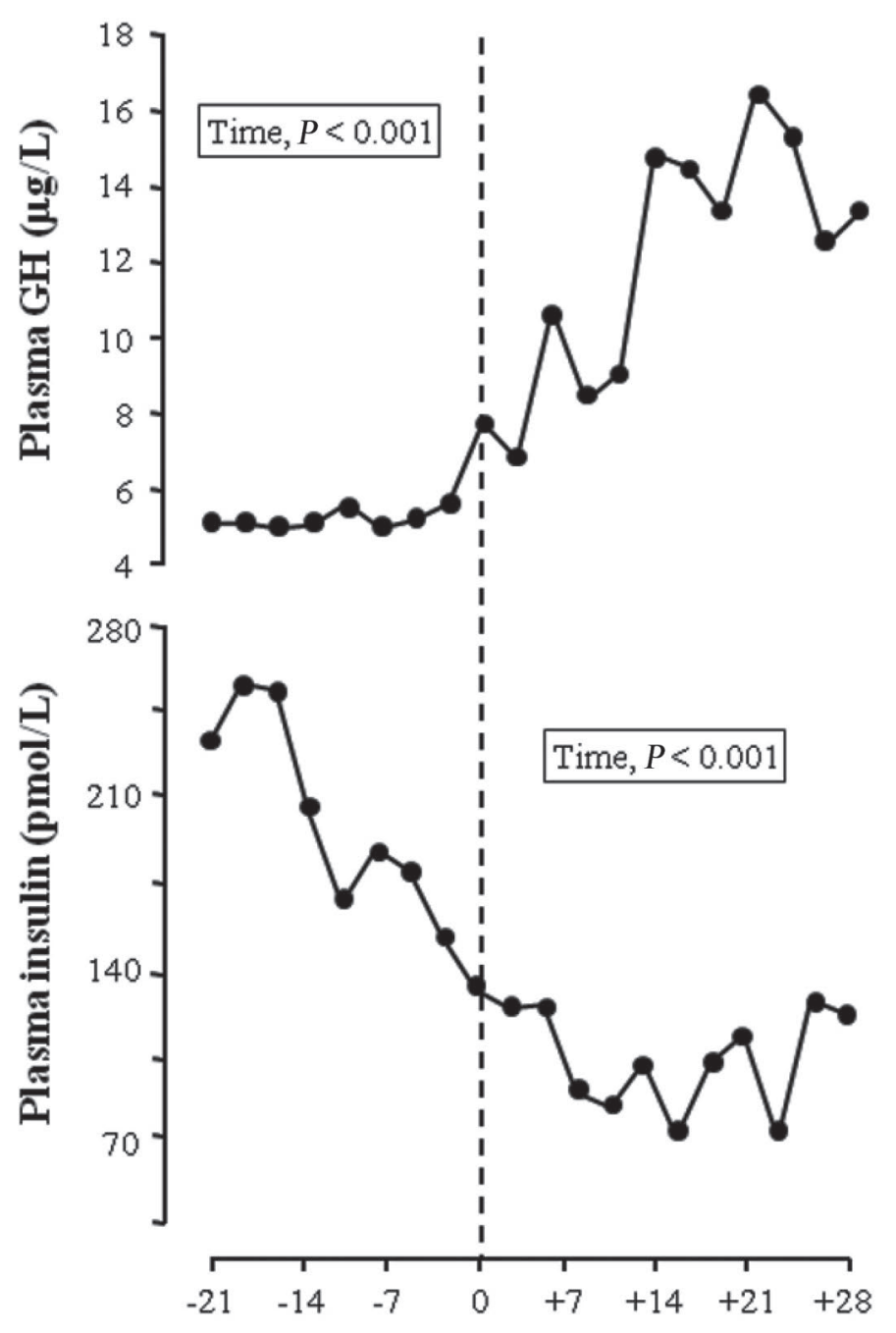

Day relative to parturition

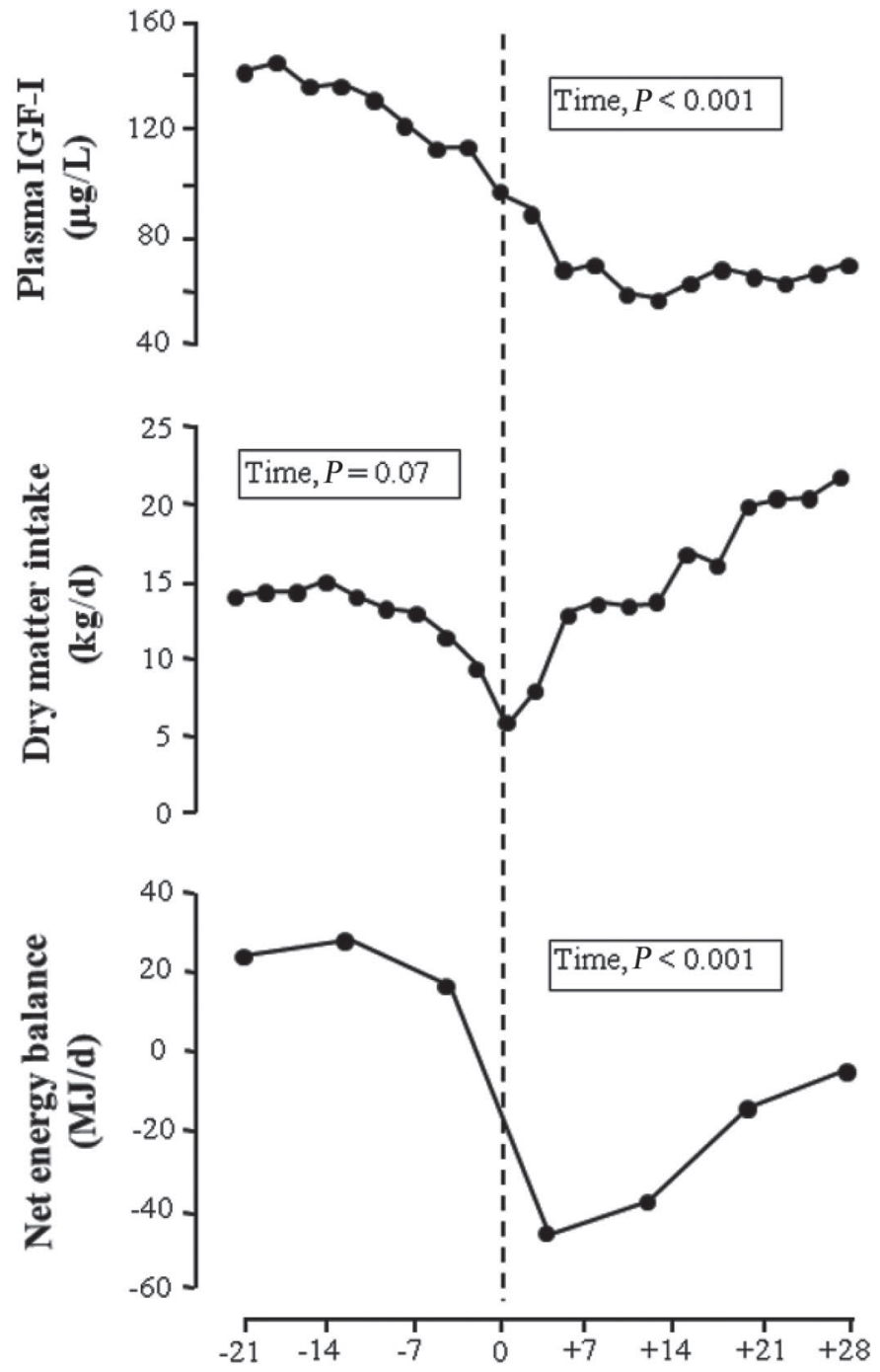

Day relative to parturition

Figure 4. Temporal pattern of whole-animal energetics and key hormones responsible for nutrient partitioning in transitioning lactating Holstein cows. Reproduced from Rhoads et al. (2004) with permission of the American Society for Nutrition. 


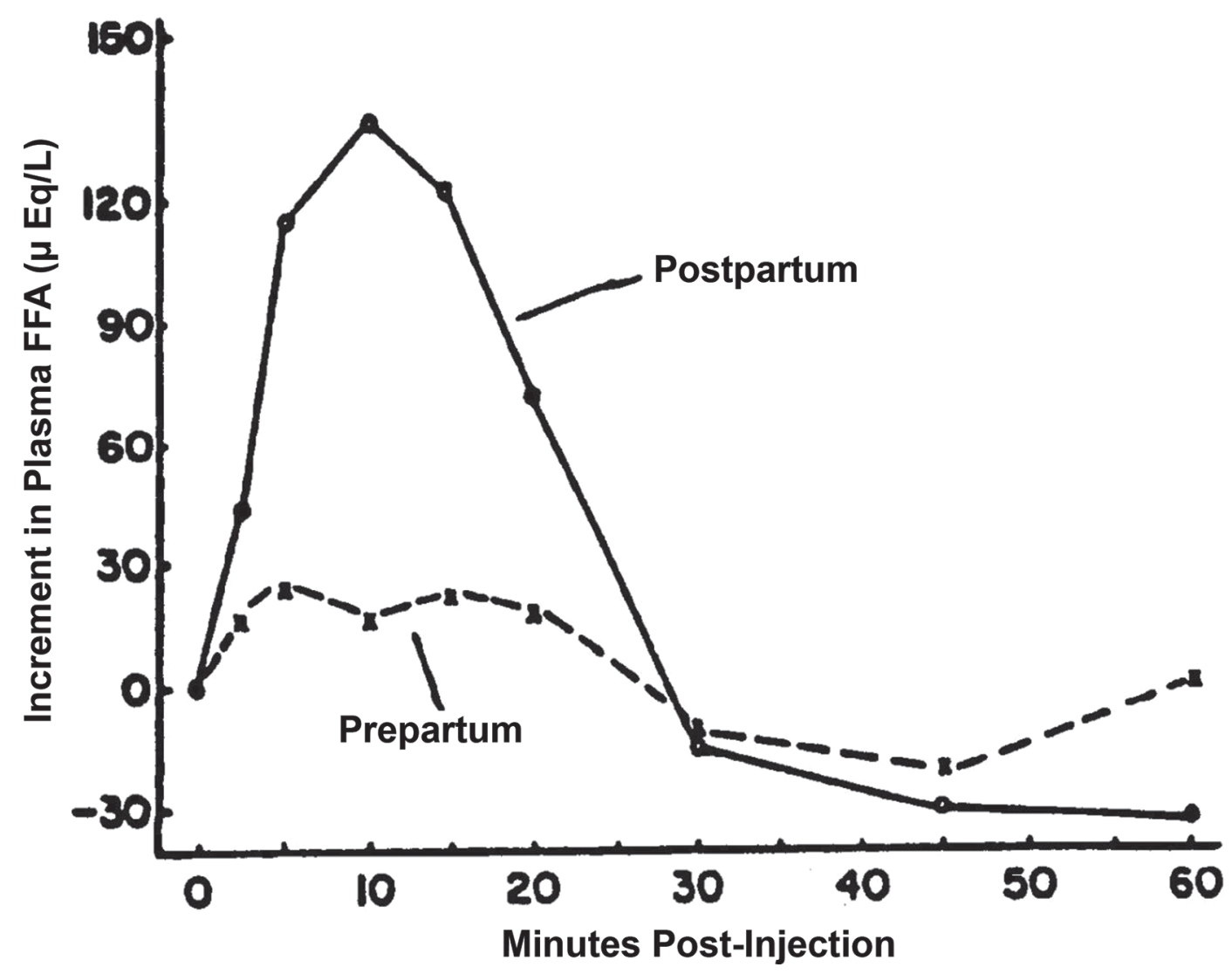

Figure 5. Effects of parturition on lipolytic response (plasma nonesterified fatty acids) to an epinephrine challenge administered intravenously at 6, 4, and 2 wk prepartum and 2, 4, and 7 wk postpartum in dairy cows. Reproduced from Bauman (1984) with permission.

(Bauman et al., 1988; Dunshea et al., 1990) and it is generally thought that there is a linear relationship (concentration-dependent process) between NEFA delivery, tissue NEFA uptake, and NEFA oxidation (Armstrong et al., 1961). The magnitude of NEBAL and thus lipid mobilization explains, in large part, why cows lose considerable BW during early lactation.

Postabsorptive carbohydrate metabolism is also markedly altered by NEBAL and this is largely mediated by reduced insulin action. During early lactation
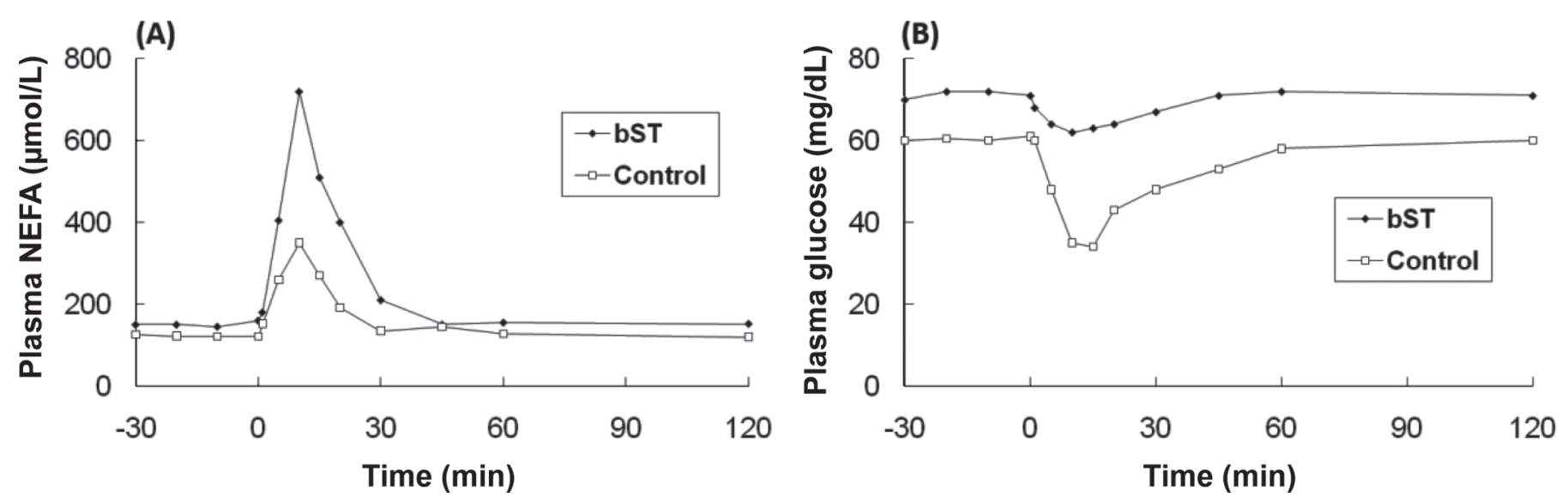

Figure 6. Effects of recombinant bST on (A) plasma nonesterified fatty acid (NEFA) response to an epinephrine challenge and (B) plasma glucose response to an insulin tolerance test in lactating Holstein cows. Reproduced from Sechen et al. (1990) with permission of the American Physiological Society. 
or inadequate nutrient intake, glucose is partitioned toward the mammary gland and its contribution as a fuel source to extra-mammary tissues is decreased (Bell, 1995). This can be observed when comparing insulin's effectiveness at stimulating muscle glucose uptake in lactating and nonlactating animals (Figure 3). The early lactation or NEBAL-induced hypoglycemia likely accentuates catecholamine's adipose lipolytic effectiveness, a phenomenon observed in other species (Galster et al., 1981). This is a key "glucose-sparing" mechanism because elevated NEFA levels decreases skeletal muscle glucose uptake and oxidation and this is referred to as the "Randle Effect" (Randle, 1998). The fact that insulin simultaneously orchestrates both carbohydrate and lipid metabolism explains why there is a reciprocal relationship between glucose and NEFA oxidation. Ultimately, these are homeorhetic adaptations to maximize milk synthesis at the expense of tissue accretion (Bauman and Currie, 1980). A cow in NEBAL could be considered "metabolically flexible" because she can depend upon alternative fuels (NEFA and ketones) to spare glucose, which can be utilized by the mammary gland to support copious milk production.

\section{CHALLENGES AND OPPORTUNITIES}

World population is projected to grow to between 9 and 10 billion people by 2050 (Godber and Wall, 2014). Most of the growth is expected to occur in poor and developing countries, where income elasticity of demand for food continues to be high. This population increase, combined with moderately high growth in income, is anticipated to result in a $>70 \%$ increase in demand for food and other agricultural products by 2050 (Godber and Wall, 2014). Meeting the increasing demand for food mandates continued improvements in agricultural productivity. Thus, the future presents both challenges and opportunities as shown by the following examples.

\section{Climate Change}

A significant portion of the world's domestic animal population exists in regions where climatic stressors adversely influence animal health and productivity. Even in the United States, the dairy industry loses approximately $\$ 1.5$ billion annually due to heat stress (St-Pierre et al., 2003; Key and Sneeringer, 2014). Substantial progress has been made over the last 3 decades in improving the productivity of ruminant livestock exposed to adverse environmental conditions, including advances in nutritional management, selective breeding, and animal housing facilities (Collier et al., 2005). Identifying specific genes associated with thermal tolerance is in the early stages, but thermal stress has a clear gene $\times$ environment interaction, indicating that opportunities may exist to improve the thermal tolerance of dairy cattle (Collier et al., 2008).

With regard to nutrient partitioning, heat-stressed cows voluntarily decrease feed intake, but the postabsorptive metabolic changes in heat-stressed cows differ markedly from those of thermal neutral cows fed at a similar plane of nutrition (Baumgard and Rhoads, 2013). Despite being in a catabolic state, heat-stressed cows have increased basal and stimulated insulin secretion, which significantly limits adipose tissue rates of lipolysis and the mobilization of energy reserves (Baumgard and Rhoads, 2013). Consequently, heatstressed cows have reduced NEFA and ketones and thus are unable to "spare" glucose for milk synthesis. Identifying mechanisms and basis for these postabsorptive strategies may allow the development of approaches (e.g., nutritional, genetic, pharmaceutical) designed to ameliorate the negative consequences of heat stress.

\section{Immunometabolism}

There is an increasing recognition of the complex and dynamic metabolic response to infection and inflammation and the role that the immune response may play in animal productivity and well-being. Immunoactivated animals voluntarily become hypophagic but have a paradoxical increase in circulating insulin (Kvidera et al., 2016, 2017). Despite the hyperinsulinemia, infection-induced decreased glucose clearance was first described over $90 \mathrm{yr}$ ago (Hector, 1926) and more recently it has been confirmed that inflammatory conditions cause whole-body insulin resistance in mid-lactation dairy cows (McGuinness, 2005; Vernay et al., 2012). Specifically, peripheral insulin insensitivity occurs in skeletal muscle and adipose tissue, the 2 largest "sinks" of insulin-stimulated glucose disposal (Lang et al., 1990). This is likely a strategy to spare glucose for the immune system as leukocytes require insulin for activation and contain GLUT4 receptors (Maratou et al., 2007).

Relative to nutrient partitioning, peripheral insulin resistance is necessary to achieve optimal milk production in healthy dairy cows as discussed earlier, but this relationship is obviously uncoupled during an infection. Mammary epithelial cells have toll-like receptors (Ibeagha-Awemu et al., 2008) and are therefore able to recognize bacterial-derived antigens. Thus, infection-induced decreased milk synthesis represents a mechanism that reduces glucose use by the mammary glands, thereby allowing increased glucose availability for the immune system. Recent estimates indicate that an intensely activated immune system utilizes more than $2 \mathrm{~kg}$ of glucose per day (Kvidera et al., 2017), so 
the implications of the immune system's demands on nutrient partitioning are obvious.

The transition period is associated with a temporal inflammatory state, and potential sources include uterine tissue damage, metritis, mastitis, and "sterile inflammation" (Bradford et al., 2015). Another more inconspicuous source of immune activation is the gastrointestinal tract. Decreased intestinal barrier function has been described in the transitioning period, heat stress, feed restriction, and rumen acidosis (Khafipour et al., 2009; Baumgard and Rhoads, 2013; Zhang et al., 2013; Abuajamieh et al., 2016). Thus, with regard to nutrient partitioning, it is not a coincidence that the metabolic, endocrine, and immune response is similar between multiple pathologies frequently observed in dairy production (Baumgard and Rhoads, 2013). Further identifying the coordination between nutrient use by the immune system and the utilization of nutrients for productive functions will likely provide novel approaches amenable to physiological manipulation.

\section{Application of Omics Research}

The burgeoning fields of genomics, proteomics, metabolomics, nutrigenomics, lipidomics, and microbiomics have provided new systems biology techniques, approaches, and data to assess key regulation in various biological processes. The ability to sequence genomes of microbes and animals has demonstrated that it is possible to improve the accuracy of selection information. Consequently, genomic selection is revolutionizing dairy cattle breeding by reducing the generation interval and increasing the accuracy of genetic selection decisions. With regards to microbiomics, recent work has shown a relationship between gut microbiota and both positive and negative aspects of animal performance and well-being. This is a largely unexplored area in ruminants, but the classic research in dietary-induced milk fat depression demonstrates its importance and potential impact on the regulation of nutrient partitioning. Recent discoveries have firmly established that ruminal biohydrogenation of polyunsaturated fatty acids results in the production of trace levels of bioactive fatty acid isomers, which can regulate postabsorptive metabolism and mammary milk fat synthesis (Bauman and Griinari, 2003; Bauman et al., 2011). Presumably, other bioactive molecules derived from gut microbial fermentation may also be absorbed and have non-nutritive roles involving metabolic regulation and overall production efficiency and well-being. Further characterization of the pathways and end-products of macronutrient fermentation (within both the rumen and large intestine) will undoubtedly contribute to our understanding of how the intestinal microbiome par- tially regulates postabsorptive nutrient trafficking and ultimately animal productivity and well-being.

Genomics is a developing technique in dairy science, and "omics" research to date has generated massive quantities of descriptive data that provide excellent baseline information. Application of these data will be especially challenging because we often have inadequate knowledge of the role and functionality of specific genes and proteins. Regulation of nutrient partitioning is complex, involving both acute and chronic orchestration of multiple tissues and physiological processes. The large amount of data harvested by "omics" techniques are noncausal, and accurately interpreting the correlated changes requires an extensive appreciation for biological principles. The challenge is applying the descriptive information gained from "omics" research to demonstrate functionality and develop a more comprehensive understanding of the regulation of these physiological processes and their role in animal productivity, health, and well-being. Clearly, translation and application of this new knowledge to improve nutrient partitioning and productive efficiency represents an area of exciting opportunity.

\section{REFERENCES}

Abuajamieh, M., S. K. Stoakes, M. V. Sanz Fernandez, A. Nayeri, N. C. Upah, E. A. Nolan, S. M. Lei, J. M. DeFrain, H. B. Green, K. M. Schoenberg, W. E. Trout, and L. H. Baumgard. 2016. Inflammatory biomarkers are closely associated with ketosis in periparturient Holstein cows. Res. Vet. Sci. 109:81-85.

Agnew, R. E., and T. Yan. 2000. Impact of recent research on energy feeding systems for dairy cattle. Livest. Prod. Sci. 66:197-215.

Armstrong, D. T., R. Steele, N. Altszuler, A. Dunn, J. S. Bishop, and R. C. De Bodo. 1961. Regulation of plasma free fatty acid turnover. Am. J. Physiol. 201:9-15.

Bauman, D. E. 1984. Regulation of nutrient partitioning. Pages 505524 in Symposium on Herbivore Nutrition in the Subtropics and Tropics. F. M. C. Gilchrist and R. I. Mackie, ed. The Science Press, Craighall, South Africa.

Bauman, D. E. 2000. Regulation of nutrient partitioning during lactation: homeostasis and homeorhesis revisited. Pages 311-327 in Ruminant Physiology: Digestion, Metabolism, Growth, and Reproduction. P. B. Cronje, ed. CAB Publishing, New York, NY.

Bauman, D. E., and J. L. Capper. 2011. Future challenges and opportunities in animal nutrition. Pages 70-84 in Proc. Southwest Nutrition and Management Conf., Tempe, AZ. University of Arizona, Tucson.

Bauman, D. E., and W. B. Currie. 1980. Partitioning of nutrients during pregnancy and lactation: a review of mechanisms involving homeostasis and homeorhesis. J. Dairy Sci. 63:1514-1529.

Bauman, D. E., J. H. Eisemann, and W. B. Currie. 1982. Hormonal effects on nutrients for tissue growth: role of growth hormone and prolactin. Fed. Proc. 41:2538-2544

Bauman, D. E., and J. M. Elliot. 1983. Control of nutrient partitioning in lactating ruminants. Pages $437-468$ in Biochemistry of Lactation. T. B. Mepham, ed. Elsevier Science Publishers B.V., Amsterdam, the Netherlands.

Bauman, D. E., and J. M. Griinari. 2003. Nutritional regulation of milk fat synthesis. Annu. Rev. Nutr. 23:203-227.

Bauman, D. E., K. J. Harvatine, and A. L. Lock. 2011. Nutrigenomics, rumen-derived bioactive fatty acids and the regulation of milk fat synthesis. Annu. Rev. Nutr. 31:299-319. 
Bauman, D. E., S. N. McCutcheon, W. D. Steinhour, P. J. Eppard, and S. J. Sechen. 1985. Sources of variation and prospects for improvement of productive efficiency in the dairy cow: A review. J. Anim. Sci. 60:583-592.

Bauman, D. E., C. J. Peel, W. D. Steinhour, P. J. Reynolds, H. F. Tyrrell, A. C. G. Brown, and G. L. Haaland. 1988. Effect of bovine somatotropin on metabolism of lactating dairy cows: Influence on rates of irreversible loss and oxidation of glucose and nonesterified fatty acids. J. Nutr. 118:1031-1040.

Bauman, D. E., and R. G. Vernon. 1993. Effects of exogenous bovine somatotropin on lactation. Annu. Rev. Nutr. 13:437-461.

Baumgard, L. H., and R. P. Rhoads. 2013. Effects of heat stress on postabsorptive metabolism and energetics. Annu. Rev. Anim. Biosci. 1:311-337.

Beever, D. E., A. Hattan, C. K. Reynolds, and S. B. Cammell. 1999 Nutrient supply to high-yielding dairy cows. Pages 119-131 in Fertility in the High-Producing Dairy Cow. M. G. Diskin, ed. Occasional Publication No 26. Br. Soc. Anim. Sci., Midlothian, UK.

Bell, A. W. 1995. Regulation of organic nutrient metabolism during transition from late pregnancy to early lactation. J. Anim. Sci. 73:2804-2819.

Bell, A. W., and D. E. Bauman. 1997. Adaptations of glucose metabolism during pregnancy and lactation. J. Mammary Gland Biol. Neoplasia 2:265-278.

Bradford, B. J., K. Yuan, J. K. Farney, L. K. Mamedova, and A. J. Carpenter. 2015. Invited review: Inflammation during the transition to lactation: New adventures with an old flame. J. Dairy Sci. 98:6631-6650.

Broom, D. M. 1999. The welfare of dairy cattle. Pages 32-39 in Future Milk Farming. FIL-IDF 25th International Dairy Congress. K. Aagaard, ed. Danish National Committee. International Dairy Federation, Aarhus, Denmark.

Brown, R. E. 1969. The conversion of nutrients into milk. Pages 23-42 in University of Nottingham Third Nutrition Conference for Feed Manufacturers. H. Swan and D. Lewis, ed. Churchill, London, UK.

Cannon, W. B. 1929. Organization for physiological homeostasis. Physiol. Rev. 9:399-431.

Capper, J. L., and D. E. Bauman. 2013. The role of productivity in improving the environmental sustainability of ruminant production systems. Annu. Rev. Anim. Biosci. 1:469-489.

Chilliard, Y. 1999 Metabolic adaptations and nutrient partitioning in the lactating animal. Pages 503-552 in Biology of Lactation.J. Martinet, L. M. Houdebine, and H. H. Head, ed. INRA Editions, Paris, France.

Collier, R. J., L. H. Baumgard, A. L. Lock, and D. E. Bauman. 2005. Physiological limitations, nutrient partitioning. Pages 351-378 in Yields of Farmed Species: Constraints and Opportunities in the 21st Century. R. Sylvester-Bradley and J. Wiseman, ed. Nottingham University Press, Nottingham, UK.

Collier, R. J., J. L. Collier, R. P. Rhoads, and L. H. Baumgard. 2008. Genes involved in the bovine heat stress response. J. Dairy Sci. 91:445-454.

Drackley, J. K. 1999. Biology of dairy cows during the transition period: The final frontier? J. Dairy Sci. 82:2259-2273.

Dunshea, F. R., A. W. Bell, and T. E. Trigg. 1990. Non-esterified fatty acid and glycerol kinetics and fatty acid re-esterification in goats during early lactation. Br. J. Nutr. 64:133-145.

Etherton, T. D., and D. E. Bauman. 1998. Biology of somatotropin in growth and lactation of domestic animals. Physiol. Rev. 78:745761 .

FAO. 2013. Mitigation of Greenhouse Gas Emissions in Livestock Production. P. J. Gerber, B. Henderson, and H. P. S. Makkar, ed. Food and Agriculture Organization of the United Nations, Rome, Italy.

Ferguson, J. D., and A. Skidmore. 2013. Reproductive performance in a select sample of dairy herds. J. Dairy Sci. 96:1269-1289.

Galster, A. D., W. E. Clutter, P. E. Cryer, J. A. Collins, and D. M. Bier. 1981. Epinephrine plasma thresholds for lipolytic effects in man: Measurements of fatty acid transport with [1-13C] palmitic acid. J. Clin. Invest. 67:1729-1738.
Gerber, P., T. Vellinga, C. Opio, and H. Steinfeld. 2011. Productivity gains and greenhouse gas emissions intensity in dairy systems. Livest. Sci. 139:100-108.

Godber, O. F., and R. Wall. 2014. Livestock and food security: Vulnerability to population growth and climate change. Glob. Chang. Biol. 20:3092-3102.

Gordon, F. J., D. C. Patterson, T. Yan, M. G. Porter, C. S. Mayne and E. F. Unsworth. 1995. The influence of genetic index for milk production on the response to complete diet feeding and the utilization of energy and nitrogen. Anim. Sci. 61:199-210.

Guesnet, P., M. Massoud, and Y. Demarne. 1987. Effects of pregnancy and lactation on lipolysis of ewe adipocytes induced by $\beta$-adrenergic stimulation. Mol. Cell. Endocrinol. 50:177-181.

Hammond, J. 1947. Annual breeding in relation to nutrition and environmental contributions. Biol. Rev. Camb. Philos. Soc. 22:195-213.

Hammond, J. 1952. Physiological limits to intensive production in animals. Br. Agric. Bull. 4:222-224.

Hart, I. C., J. A. Bines, S. V. Morant, and J. L. Ridley. 1978. Endocrine control of energy metabolism in the cow: comparison of the levels of hormones (prolactin, growth hormone, insulin and thyroxine) and metabolites in the plasma of high- and low-yielding cows at various stages of lactation. J. Endocrinol. 77:333-345.

Hector, F. J. 1926. Carbohydrate metabolism in diphtheria. Lancet 208:642-645.

Ibeagha-Awemu, E. M., J. W. Lee, A. E. Ibeagha, D. D. Bannerman, M. J. Paape, and X. Zhao. 2008. Bacterial lipopolysaccharide induces increased expression of toll-like receptor (TLR) 4 and downstream TLR signaling molecules in bovine mammary epithelial cells. Vet. Res. 39:11.

Kahn, C. R. 1978. Insulin resistance, insulin insensitivity, and insulin unresponsiveness: A necessary distinction. Metabolism 27:18931902.

Key, N., and S. Sneeringer. 2014. Potential effects of climate change on the productivity of US dairies. Am. J. Agric. Econ. 96:1136-1156. https://doi.org/10.1093/ajae/aau002.

Khafipour, E., D. O. Krause, and J. C. Plaizier. 2009. A grain-based subacute ruminal acidosis challenge causes translocation of lipopolysaccharide and triggers inflammation. J. Dairy Sci. 92:10601070

Kleiber, M. 1961. Fire of Life: An Introduction to Animal Energetics. John Wiley \& Sons, New York, NY.

Knight, C. H., M. A. Alamer, A. Sorensen, I. M. Nevison, D. J. Flint, and R. G. Vernon. 2004. Metabolic safety-margins do not differ between cows of high and low genetic merit for milk production. J. Dairy Res. 71:141-153.

Kvidera, S. K., E. A. Horst, M. Abuajamieh, E. J. Mayorga, M. V. Sanz Fernandez, and L. H. Baumgard. 2016. Technical note: A procedure to estimate glucose requirements of an activated immune system in steers. J. Anim. Sci. 94:4591-4599.

Kvidera, S. K., E. A. Horst, M. Abuajamieh, E. J. Mayorga, M. V. Sanz Fernandez, and L. H. Baumgard. 2017. Glucose requirements of an activated immune system in lactating Holstein cows. J. Dairy Sci. 100:2360-2374.

Lang, C. H., C. Dobrescu, and K. Mészáros. 1990. Insulin-mediated glucose uptake by individual tissues during sepsis. Metabolism 39:1096-1107.

Maratou, E., G. Dimitriadis, A. Kollias, E. Boutati, V. Lambadiari, P. Mitrou, and S. A. Raptis. 2007. Glucose transporter expression on the plasma membrane of resting and activated white blood cells. Eur. J. Clin. Invest. 37:282-290.

McGuinness, O. P. 2005. Defective glucose homeostasis during infection. Annu. Rev. Nutr. 25:9-35.

McNamara, J. P. 1988. Regulation of bovine adipose tissue metabolism during lactation. 4. Dose-responsiveness to epinephrine as altered by stage of lactation. J. Dairy Sci. 71:643-649.

McNamara, J. P. 1991. Regulation of adipose tissue metabolism in support of lactation. J. Dairy Sci. 74:706-719.

McNamara, J. P. 2015. Systems biology of regulatory mechanisms of nutrient metabolism in lactation. J. Anim. Sci. 93:5575-5585.

Moraes, L. E., E. Kebreab, A. B. Strathe, J. Dijkstra, J. France, D. P. Casper, and J. G. Fadel. 2015. Multivariate and univariate analy- 
sis of energy balance data from lactating dairy cows. J. Dairy Sci. 98:4012-4029.

Oltenacu, P. A., and D. M. Broom. 2010. The impact of genetic selection for increased milk yield on the welfare of dairy cows. Anim. Welf. 19:39-49.

Patton, S. 2004. Milk: Its Remarkable Contribution to Human Health and Well-Being. Transaction Publishers, New Brunswick, NJ.

Randle, P. J. 1998. Regulatory interactions between lipids and carbohydrates: The glucose fatty acid cycle after 35 years. Diabetes Metab. Rev. 14:263-283.

Reynolds, C. K. 2004. Metabolic consequences of increasing milk yield-Revisiting Lorna. Pages 73-83 in UK dairying: Using Science to Meet Consumers' Needs. E. Kebreab, J. Mills, and D. Beever, ed. Nottingham University Press, Nottingham, UK.

Rhoads, R. P., J. W. Kim, B. J. Leury, L. H. Baumgard, N. Segoale, S. J. Frank, D. E. Bauman, and Y. R. Boisclair. 2004. Insulin increases the abundance of the growth hormone receptor in liver and adipose tissue of periparturient cows. J. Nutr. 134:1020-1027.

Roche, J. R., and D. E. Edmeades. 2004. The paradigm of efficiency and sustainability-A dairying perspective. S. Afr. J. Anim. Sci. 34(Suppl. 2):8-16.

Santos, J. E. P., R. S. Bisinotto, E. S. Ribeiro, F. S. Lima, L. F. Greco, C. R. Staples, and W. W. Thatcher. 2010. Applying nutrition and physiology to improve reproduction in dairy cattle. Soc. Reprod. Fertil. Suppl. 67:387-403.

Sechen, S. J., F. R. Dunshea, and D. E. Bauman. 1990. Somatropin in lactating cows: Effect on response to epinephrine and insulin. Am. J. Physiol. 258:E582-E588

Shook, G. E. 2006. Major advances in determining appropriate selection goals. J. Dairy Sci. 89:1349-1361.
St-Pierre, N. R., B. Cobanov, and G. Schnitkey. 2003. Economic losses from heat stress by US livestock industries. J. Dairy Sci. 86:E52E77.

VandeHaar, M. J., and N. St-Pierre. 2006. Major advances in nutrition: Relevance to the sustainability of the dairy industry. J. Dairy Sci. 89:1280-1291.

VanRaden, P. M. 2004. Invited review: Selection on net merit to improve lifetime profit. J. Dairy Sci. 87:3125-3131.

Vernay, M. C., O. Wellnitz, L. Kreipe, H. A. van Dorland, and R. M. Bruckmaier. 2012. Local and systemic response to intramammary lipopolysaccharide challenge during long-term manipulated plasma glucose and insulin concentrations in dairy cows. J. Dairy Sci. 95:2540-2549

Vernon, R. G. 1986. The response of tissues to hormones and the partition of nutrients during lactation. Pages 115-121 in Research Reviews, Hannah Yearbook. Hannah Research Institute, Ayr, UK.

Vernon, R. G. 1989. Endocrine control of metabolic adaptation during lactation. Proc. Nutr. Soc. 48:23-32.

Vernon, R. G., E. Finley, and P. W. Watt. 1991. Adenosine and the control of adrenergic regulation of adipose tissue lipolysis during lactation. J. Dairy Sci. 74:695-705.

Vernon, R. G., and S. Sasaki. 1991. Control of responsiveness of tissue to hormones. Pages 155-182 in Physiological Aspects of Digestion and Metabolism in Ruminants. T. Tsuda, Y. Sasaki, and R. Kawashima, ed. Academic Press Inc., San Diego, CA.

Zhang, S., R. I. Albornoz, J. R. Aschenbach, D. R. Barreda, and G. B. Penner. 2013. Short-term feed restriction impairs the absorptive function of the reticulo-rumen and total tract barrier function in beef cattle. J. Anim. Sci. 91:1685-1695.

\section{APPENDIX}

Table A1. Major milestones in the study of nutrient partitioning to support lactation

\begin{tabular}{|l|l|l|}
\hline Date & Milestone & Reference \\
\hline 1923 & Insulin's role in milk composition is defined. & \\
\hline 1929 & Concept of homeostasis is elucidated. & Cannon, 1929 \\
\hline 1932 & Pituitary extract injected into cows. & \\
\hline 1945 & $\begin{array}{l}\text { First National Research Council report: Recommended Nutrient } \\
\text { Allowances for Dairy Cattle. }\end{array}$ & \\
\hline 1953 & Annual milk/cow is approximately 2,500 kg. & https://quickstats.usda.nass/ \\
\hline $1960 \mathrm{~s}$ & Rov/ \\
\hline $1960 \mathrm{~s}$ & defined. & \\
\hline $1960 \mathrm{~s}$ & Mammary balance sheet of nutrient uptake and use. & \\
\hline 1963 & Production of VFA by rumen fermentation established. & \\
\hline
\end{tabular}


Table A1 (Continued). Major milestones in study of nutrient partitioning to support lactation

\begin{tabular}{|c|c|c|}
\hline Date & Milestone & Reference \\
\hline Mid-1960s-1970s & Biochemical pathways of milk fat synthesis are elucidated. & \\
\hline Mid-1960s-1970s & Biochemical pathways of milk lactose synthesis are elucidated. & \\
\hline 1970s & $\begin{array}{l}\text { Biochemical pathways for milk protein synthesis are } \\
\text { elucidated. }\end{array}$ & \\
\hline 1977 & Annual milk/cow exceeds 5,000 kg. & $\begin{array}{l}\text { https://quickstats.usda.nass/ } \\
\text { gov/ }\end{array}$ \\
\hline 1980 & Concept of homeorhesis is proposed. & $\begin{array}{l}\text { Bauman and Currie, 1980; } \\
\text { Bauman, } 2000\end{array}$ \\
\hline 1982 & $\begin{array}{l}\text { High-yielding cows are shown to have decreased insulin and } \\
\text { increased somatotropin. }\end{array}$ & \\
\hline 1980s & $\begin{array}{l}\text { Nutritional, environmental, and genetic effects on milk } \\
\text { composition are demonstrated. }\end{array}$ & \\
\hline Late 1980s & Metabolic modeling. & \\
\hline 1994 & US Food and Drug Administration approves recombinant bST. & \\
\hline Late 1990s-early 2000s & Basis for diet-induced milk fat depression is defined. & \\
\hline
\end{tabular}

